\title{
Biostimulants on mineral nutrition and fiber quality of cotton crop
}

\author{
Ricardo de A. Silva ${ }^{1}$, Jerffson L. Santos ${ }^{1}$, Luan S. Oliveira ${ }^{1}$, Mauricio R. S. Soares ${ }^{1} \&$ Saad M. S. dos Santos ${ }^{1}$ \\ ${ }^{1}$ Universidade Estadual do Sudoeste da Bahia/Departamento de Fitotecnia e Zootecnia. Vitória da Conquista, BA. E-mail: ricardo_deandrade@yahoo.com.br \\ (Corresponding author); je.lucas@hotmail.com; luanoliveirac@yahoo.com.br; mauriciouesb@hotmail.com; saadmiranda@yahoo.com.br
}

\section{Key words:}

growth regulators

yield

foliar nutrition

Gossypium hirsutum L.

\begin{abstract}
A B S T R A C T
Biostimulants are used in cotton (Gossypium hirsutum L.) to balance vegetative and reproductive growth as well as to increase cotton seed yield and fiber quality. Therefore, in order to study the efficiency of seed treatment with biostimulants, nutrition, production and technological quality for the cotton fiber, a field experiment was installed. The study was conducted at the Alvorada farm research field, in Luis Eduardo Magalhães municipality - BA. The experiment was arranged in a completely randomized block design with four replicates and five treatments (control group, untreated group, Booster ${ }^{\circledast}$, Stimulate ${ }^{\circledast}$, Improver $^{\circledast}$ and Biozyme ${ }^{\circledast}$ ). Leaf contents of nutrients, yield and technological quality of the fiber were evaluated. The results showed that application of biostimulants in the seeds increased the N, K, S and Fe contents in the cotton leaf, but there was no influence on the crop yield. However, these products caused changes in the fiber characteristics, related to length uniformity, micronaire, length and strength of the fiber.
\end{abstract}

\section{Palavras-chave:} reguladores de crescimento produtividade nutrição foliar Gossypium hirsutum L.

\section{Bioestimulantes na nutrição mineral e qualidade de fibra na cultura do algodão}

\section{R E S U M O}

Os bioestimulantes são usados na cultura do algodão (Gossypium hirsutum L.) para equilibrar o crescimento vegetativo e reprodutivo e aumentar o rendimento de algodão em caroço e qualidade da fibra. Assim, com objetivo de estudar a eficiência do tratamento de sementes com bioestimulantes na nutrição, na produção e na qualidade tecnológica da fibra do algodoeiro, foi instalado um experimento de campo. O estudo foi realizado no campo de pesquisas da Fazenda Alvorada localizada no município de Luís Eduardo Magalhães, BA. O experimento foi conduzido em delineamento em blocos casualizados com quatro repetições e cinco tratamentos (testemunha, sem aplicação, Booster ${ }^{\circledast}$, Stimulate ${ }^{\circledR}$, Improver e Biozyme ${ }^{\circledast}$ ). Foram avaliados os teores de macro e micronutrientes foliares, produtividade e qualidade tecnológica da fibra. Os resultados mostraram que a aplicação dos bioestimulantes via semente incrementou os teores de $\mathrm{N}, \mathrm{K}, \mathrm{S}$ e Fe na parte aérea do algodoeiro mas não influenciou na produtividade; no entanto, verificaram-se alterações nas características tecnológicas da fibra em relação à uniformidade de comprimento, resistência à ruptura, índice de micronaire e comprimento da fibra. 


\section{INTRODUCTION}

In Brazil, to increase the cotton production, it is necessary to use certified seed and technologies that enable plants to express their maximum genetic potential. Among these characteristics, the use of bioregulators stands out, as they may be applied to seeds, plants and soil in order to cause morphological and physiological changes seeking to increase yield and quality of seeds (Dourado Neto et al., 2014) and/or fiber.

Bioregulators and biostimulants have been widely studied in crops of great economic importance, such as cotton, soybean, corn and bean (Lima et al., 2006; Dourado Neto et al., 2007). However, studies on cotton production that characterize the effects of theses on nutrition and fiber quality are just starting. In technified systems, the use of such products is associated with nutritional supplementation by seed treatment.

Several studies have found high rates of soils with deficiency or toxicity caused by various elements in all parts of Brazil, and those that have more critical levels of deficiency are Mo, Co, Zn, $\mathrm{Cu}, \mathrm{Mn}$ and B, especially in the Cerrado biome (Binsfeld et al., 2014). Experiments carried out using bioregulators in annual crops are inconsistent and the results do not always enable the adoption of this practice in a systematic way. However, according to Çopur et al. (2010), there was an increase in the number of seeds per fruit, plant height, earliness index, number of bolls, boll mass and improvement in the technological quality of the fiber with the application of gibberellin-based biostimulants.

Regarding the application effects of the plant bioregulators on the nutritional content, Almeida \& Soratto (2014) found, in the bean crop, that treatments with biostimulants showed higher levels of $\mathrm{K}, \mathrm{Mg}, \mathrm{Ca}, \mathrm{S}, \mathrm{Mn}, \mathrm{Fe}$ and $\mathrm{B}$, although Lana et al. (2009) found no increase in macro and micronutrients in bean plants treated with biostimulants.

Given the above, this research aimed to study the efficiency of seed treatment with biostimulants in the nutrition, yield and technological quality of the cotton fiber.

\section{Material AND Methods}

The experiment was installed on January $10^{\text {th }}, 2015$, at the Alvorada farm research field, in the municipality of Luís Eduardo Magalhães, BA, Brazil. The soil was classified as Dystrophic Red-Yellow Latosol (Oxisol) (Santos et al., 2013). Chemical characteristics of the soil for the experimental area in the layers of 0-20 and 20-40 $\mathrm{cm}$ are shown in Table 1. The area was planted with soybean and corn, respectively, in the two previous crop years and, before sowing the field with cotton, $800 \mathrm{~kg} \mathrm{ha}^{-1}$ of single superphosphate and $800 \mathrm{~kg} \mathrm{ha}^{-1}$ of monoammonium phosphate were applied.

The farming system was rainfed. The total rainfall, during the crop cycle was $1156 \mathrm{~mm}$ with an average temperature and relative humidity of $26.4{ }^{\circ} \mathrm{C}$ and $80.7 \%$, respectively, which are in accordance with the needs for the satisfactory yield of the crop.

The experiment was arranged in a completely randomized block design with four replicates, in which five treatments were evaluated, consisting of a control and four bioregulators: T1 control group, untreated; T2 - Booster ${ }^{\otimes}$ (2.3\% of Mo, 3.5\% of $\mathrm{Zn}$, and $0.0035 \%$ of kinetin and indoleacetic acid) $\left(500 \mathrm{~mL} \mathrm{ha}^{-1}\right)$; T3 - Stimulate ${ }^{\varpi}(0.005 \%$ of IBA, $0.009 \%$ of kinetin, and $0.005 \%$ of gibberellic acid) $\left(500 \mathrm{~mL} \mathrm{ha}^{-1}\right)$; T4 - Improver ${ }^{\circledR}(2.0 \%$ of molybdenum) (120 mL ha $\left.{ }^{-1}\right)$; and T5 - Biozyme ${ }^{\circledast}$ (1.50\% of $\mathrm{N}, 5.00 \%$ of $\mathrm{K}, 0.10 \%$ of $\mathrm{S}, 0.14 \%$ of $\mathrm{Mg}, 0.08 \%$ of $\mathrm{B} 0.44 \%$ of Fe, $0.10 \% \mathrm{Mn}, 0.20 \%$ of $\mathrm{Zn}, 2.00 \%$ of total organic carbon, $0.0031 \%$ of gibberellic acid and indoleacetic acid, and $0.0083 \%$ of zeatin) $\left(200 \mathrm{~mL} \mathrm{ha}^{-1}\right)$. The bioregulators were applied via seeds, shortly before sowing.

The cultivar used in the experiment was the DP 1240 BT2RRFlex, with medium cycle, at the spacing of $0.76 \mathrm{~m}$ between rows and the calculated density of 100,000 plants per hectare. Sowing was performed manually and the seeds were treated with chlorantraniliprole, fipronil, carbendazim and benzimidazole $\left(1.0,0.2,0.35\right.$ and $0.1 \mathrm{~L}$ or kg $100 \mathrm{~kg}^{-1}$ seed, respectively, applied just before planting). The plots were four 6-m-long rows and the usable area corresponded to two central rows at $0.5 \mathrm{~m}$ from each extremity.

The top-dressing fertilization consisted of $300 \mathrm{~kg} \mathrm{ha}^{-1}$ of $\mathrm{KCl}, 600 \mathrm{~kg} \mathrm{ha}^{-1}$ of ammonium sulfate, $200 \mathrm{~kg} \mathrm{ha}^{-1}$ of urea, 2 $\mathrm{kg} \mathrm{ha}^{-1}$ of Mn, $290 \mathrm{~g} \mathrm{ha}^{-1}$ of B, $50 \mathrm{~g} \mathrm{ha}^{-1}$ of $\mathrm{Zn}$ and $100 \mathrm{~g} \mathrm{~h}^{-1}$ of amino acids, applied three times during the cycle (20, 40 and 60 days after emergence). The experiment was kept free from pests through chemical control and from weeds through hand weeding.

Macro and micronutrients were determined on the $60^{\text {th }}$ day after emergence (DAE), in the fifth fully expanded leaf toward the base, during the peak of absorption of water and nutrients by the crop, in the usable area of the plot, following the recommendations of Silva (1999). To evaluate the seed cotton yield, the usable area of the plot was manually harvested. Afterwards, the material was weighed and the final yield was extrapolated to $\mathrm{kg} \mathrm{ha}^{-1}$ following the methodology proposed by Santos et al. (2014).

The analysis of the technological characteristics of the fiber was performed in the laboratory. Therefore, 50 bolls were collected from the middle third of the plants in the usable area, which were ginned and evaluated by HVI (high volume instrument) (Zellweger Uster/Spinlab 900 series), for the determination of the following variables: length uniformity (UI), strength (STR), micronaire (MIC) and length uniformity index (UHML).

Data were analyzed for variance by the F test and the means were compared by Tukey's test at 0.05 probability level using the Sisvar 5.5 software (Ferreira, 2011).

Table 1. Chemical analysis of the soil in the experimental area in the layers of $0-20$ and $20-40 \mathrm{~cm}$

\begin{tabular}{|c|c|c|c|c|c|c|c|c|c|c|c|}
\hline \multirow{2}{*}{$\begin{array}{l}\text { Layer } \\
\mathbf{c m}\end{array}$} & \multirow{2}{*}{$\begin{array}{c}\mathrm{pH} \\
\mathrm{H}_{2} \mathrm{O}\end{array}$} & $\mathbf{P}$ & $\bar{K}$ & $S$ & $\mathrm{Ca}$ & $\mathrm{Mg}$ & $\overline{A I}$ & $\mathrm{H}+\mathrm{Al}$ & \multirow[b]{2}{*}{ CEC } & \multirow{2}{*}{$\begin{array}{l}\mathbf{V} \\
\%\end{array}$} & \multirow{2}{*}{$\begin{array}{c}\mathrm{OM} \\
\mathrm{g} \mathrm{dm}\end{array}$} \\
\hline & & \multicolumn{3}{|c|}{$\mathrm{mg} \mathrm{dm}^{-3}$} & \multicolumn{4}{|c|}{$\mathrm{cmol}_{\mathrm{c}} \mathrm{dm}^{-3}$} & & & \\
\hline $0-20$ & 5.8 & 51.6 & 101.0 & 5.0 & 1.9 & 0.4 & 0.0 & 1.6 & 4.2 & 61.5 & 16.0 \\
\hline $20-40$ & 5.8 & 24.5 & 102.0 & 6.0 & 1.3 & 0.3 & 0.0 & 1.5 & 3.4 & 55.4 & 12.0 \\
\hline
\end{tabular}




\section{Results AND Discussion}

For contents of $\mathrm{N}, \mathrm{K}, \mathrm{S}$ and $\mathrm{Fe}$ in the leaf, there were significant differences between biostimulants; however, the contents of $\mathrm{P}, \mathrm{Ca}, \mathrm{Mg}, \mathrm{Cu}, \mathrm{Mn}$, and $\mathrm{Zn}$ were not changed by the application of Booster ${ }^{\oplus}$, Stimulate, and Improver ${ }^{\bullet}$ (Table 2). Lana et al. (2009), applying the Stimulate ${ }^{\circ}$ and Kelpak ${ }^{\circ}$ biostimulants in seed treatment and foliar applications, found that these products did not influence the content of macro and micronutrients in the bean crop leaf.

There was no effect for the application of biostimulants on cotton yield (Table 2). As the products were applied for the seed treatment, it did not result in higher yields; maybe the effect of the products is localized when applied to the seed, restricted only to the crop establishment stage. Pedroso Neto et al. (2006) found higher yield when the seeds were treated with $\mathrm{N}, \mathrm{P}, \mathrm{K}, \mathrm{Zn}$ and $\mathrm{B}$, but at contents 20 times higher than those contained in Biozyme ${ }^{\circ}$ and Improver ${ }^{\circ}$.

Biostimulants influenced the technological fiber characteristics (Table 2). The biosynthesis of cotton fiber is a complex process that depends on the plant nutritional status and adequate abiotic conditions. This phase is characterized by over-production of gibberellin, which directly influences micronaire, length and strength of the fiber (Wang et al., 2010). Therefore, the exogenous application of biostimulants may increase the gibberellin content of the plant, resulting in changes in fiber formation.

The $\mathrm{N}$ content was higher in plants that received Improver ${ }^{\circ}$ application in the seed treatment compared with the control group, while the other treatments were similar to the control (Table 3). This effect is related to the Mo content contained in the product, $23.54 \%$. According to Gelain et al. (2011), Mo is an essential element for the activity of nitrate reductase, which reduces nitrate to nitrite, which is directly related to the supply of the $\mathrm{N}$ to the plant. According to the authors, the application of molybdenum fertilizer via seed treatment is more indicated because it is more practical and effective in relation to the soil or foliar applications.
Table 3. Macronutrient (nitrogen - $\mathrm{N}$, phosphorus - $\mathrm{P}$, potassium - $\mathrm{K}$, calcium - $\mathrm{Ca}$, magnesium - Mg and sulfur S) contents, in the leaves of cotton plants originated from seeds treated with bioregulators on the 60th day after the emergence

\begin{tabular}{lcccccc}
\hline \multirow{2}{*}{ Treatment } & $\mathbf{N}$ & $\mathbf{P}$ & $\mathbf{K}$ & $\mathbf{C a}$ & $\mathbf{M g}$ & $\mathbf{S}$ \\
\cline { 2 - 6 } & \multicolumn{5}{c}{$\mathbf{g ~ k g}^{-1}$} \\
Control group $^{-}$ & $40.68 \mathrm{~b}$ & $3.38 \mathrm{a}$ & $19.90 \mathrm{~b}$ & $22.77 \mathrm{a}$ & $4.11 \mathrm{a}$ & $6.72 \mathrm{~b}$ \\
Booster $^{\circledR}$ & $43.77 \mathrm{ab}$ & $4.00 \mathrm{a}$ & $21.85 \mathrm{a}$ & $25.79 \mathrm{a}$ & $4.05 \mathrm{a}$ & $7.98 \mathrm{a}$ \\
Stimulate $^{\circledR}$ & $43.18 \mathrm{ab}$ & $4.00 \mathrm{a}$ & $21.72 \mathrm{a}$ & $25.27 \mathrm{a}$ & $4.12 \mathrm{a}$ & $7.75 \mathrm{ab}$ \\
Improver $^{\circledR}$ & $43.84 \mathrm{a}$ & $4.05 \mathrm{a}$ & $21.64 \mathrm{a}$ & $23.74 \mathrm{a}$ & $4.13 \mathrm{a}$ & $7.48 \mathrm{ab}$ \\
Biozyme $^{\circledR}$ & $42.82 \mathrm{ab}$ & $4.00 \mathrm{a}$ & $21.52 \mathrm{ab}$ & $23.27 \mathrm{a}$ & $4.01 \mathrm{a}$ & $7.20 \mathrm{ab}$ \\
\hline
\end{tabular}

Means followed by the same letter in the column do not differ by Tukey's test at 0.05 probability level

The levels of $\mathrm{P}, \mathrm{Ca}$ and $\mathrm{Mg}$ were not affected by the application of the studied products, compared with the control group (Table 2). These results are in agreement with Almeida \& Soratto (2014), who stated that the application of biostimulants did not affect root growth and, consequently, there was no effect on soil exploration and P uptake by the bean crop. For $\mathrm{Ca}$ and $\mathrm{Mg}$, liming was possibly enough to meet crop needs. Similar results were found by Silva et al. (2009).

Regarding K, the treatments with Booster ${ }^{\oplus}$, Stimulate ${ }^{\circ}$ and Improver ${ }^{\oplus}$ showed higher $\mathrm{K}$ levels in comparison to the control group (Table 3 ). $\mathrm{K}$ is directly related to biochemical activities, enzyme activation, opening and closing of stomata, photosynthesis and fruit formation (Barragán et al., 2012). This result differs from those found by Silva et al. (2009) and Almeida \& Soratto (2014), in the bean crop.

For sulfur content in the cotton leaves, only the Booster treatment was superior to the control (Table 3). This occurs because the molybdenum is a cofactor of the enzyme xanthine oxidase, which, under drought stress conditions using L-cysteine amino acid as S provider (Bittner et al., 2001), increases the content of the nutrient in the leaves.

The chemical analysis of the plants, conducted on the $60^{\text {th }} \mathrm{DAE}$, revealed that none of the studied biostimulants significantly altered the contents of $\mathrm{Cu}, \mathrm{Mn}$ and $\mathrm{Zn}$ in the

Table 2. Analysis of variance related to contents of macro and micronutrients in the leaf, yield, micronaire (MIC), fiber length (UHML), fiber uniformity index (UI) and fiber strength (STR) of cotton plants originated from seeds treated with plant bioregulators on the $60^{\text {th }}$ day after emergence

\begin{tabular}{|c|c|c|c|c|c|c|c|}
\hline \multirow{3}{*}{ SV } & \multirow{3}{*}{ D.F. } & \multicolumn{6}{|c|}{ Mean squares } \\
\hline & & \multicolumn{6}{|c|}{ Macronutrients } \\
\hline & & $\bar{N}$ & $\bar{P}$ & $\bar{K}$ & $\mathrm{Ca}$ & $\mathrm{Mg}$ & $S$ \\
\hline Treatment & 4 & $6.0421^{*}$ & $0.0205^{\mathrm{ns}}$ & $2.6128 * \star$ & $6.8002^{\mathrm{ns}}$ & $0.0110^{\text {ns }}$ & $0.9768^{*}$ \\
\hline Block & 3 & $0.0741^{\text {ns }}$ & $0.0082^{\mathrm{ns}}$ & $0.724^{\mathrm{ns}}$ & $3.675^{\mathrm{ns}}$ & $0.0409^{\text {ns }}$ & $0.1991^{\text {ns }}$ \\
\hline Error & 12 & 1.9118 & 0.0124 & 0.5324 & 7.2442 & 0.0372 & 0.2364 \\
\hline CV (\%) & & 3.23 & 2.79 & 3.42 & 11.16 & 4.72 & 6.54 \\
\hline \multirow{2}{*}{ SV } & \multirow{2}{*}{ D.F. } & \multicolumn{6}{|c|}{ Micronutrients } \\
\hline & & $\mathrm{Cu}$ & $\mathrm{Fe}$ & & & $\mathrm{Zn}$ & B \\
\hline Treatment & 4 & $0.6946^{\mathrm{ns}}$ & $331.1419 * *$ & & & $2.5501^{\mathrm{ns}}$ & $1.7245^{\mathrm{ns}}$ \\
\hline Block & 3 & $0.2414^{\mathrm{ns}}$ & $23.5797^{\mathrm{ns}}$ & & & $2.6981^{\text {ns }}$ & $0.4403^{\text {ns }}$ \\
\hline Error & 12 & 0.2199 & 15.3143 & & & 2.5059 & 1.0697 \\
\hline CV (\%) & & 13.97 & 3.12 & & & 3.56 & 2.33 \\
\hline \multirow{2}{*}{ SV } & \multirow{2}{*}{ D.F. } & \multicolumn{6}{|c|}{ Yield and technological quality of the fiber } \\
\hline & & $\bar{Y}$ & MIC & & & UI & STR \\
\hline Treatment & 4 & $18675.87^{\text {ns }}$ & $0.1130 * \star$ & & & $4.567^{\star \star}$ & $8.362^{\star *}$ \\
\hline Bloc & 3 & $388329.87^{\text {ns }}$ & $0.0066^{\mathrm{ns}}$ & & & $0.1365^{\mathrm{ns}}$ & $0.1178^{\text {ns }}$ \\
\hline Error & 12 & 145641.57 & 0.01 & & & 0.1723 & 0.292 \\
\hline CV (\%) & & 8.40 & 2.28 & & & 0.5 & 1.74 \\
\hline
\end{tabular}

${ }^{* *}$ Significant at 0.01 of probability $(p<0.01) ;{ }^{*}$ significant at 0.05 of probability $(0.01 \leq p<0.05)$, ns no significant $(p \geq 0.05)$ 
cotton leaves (Table 4). These results are probably due to the low quantities of these elements required by the crop; thus, only the foliar fertilization is enough to meet the crop's needs.

As to the accumulation of Fe in the leaf, all the biostimulants were statistically superior to the control (Table 4). This effect is important because, according to Almeida \& Soratto (2014), this micronutrient acts as an enzymatic activator in processes of light absorption and nitrogen reduction.

In the evaluation of the different biostimulants, no difference was observed between the means for yield (Table 5). Oosterhuis \& Robertson (2000) also did not find any effect of foliar spraying application of growth promoters on cotton yield. These findings do not corroborate Çopur et al. (2010), who observed higher yield in cotton when applying biostimulant, Maxicrop, Biozyme TF and Biogibb, compared with the control, without application.

Regarding the technological characteristics of the fiber, STR was the only feature in the control treatment with values below those of the Biostimulants Booster ${ }^{\circledast}$, Stimulate ${ }^{\circledast}$ and Improver ${ }^{\varpi}$. However, with regard to the Micronaire, the indexes in the treatments with Booster ${ }^{\circledast}$, Improver ${ }^{\circledast}$ and Biozyme ${ }^{\circledR}$ were superior to those observed in the seed treated with Stimulate ${ }^{\circledast}$. It was found out that the application of Improver ${ }^{\circledR}$ leads to longer fiber length compared with Booster ${ }^{\circledast}$ (Table 5). The observed micronaire indexes are considered to be regular according to Fonseca \& Santana (2002) in accordance with the classification rules, and fibers with length superior to $30.6 \mathrm{~mm}$ are considered as long fibers (Brasil, 2002). Therefore, the studied variety can be considered to be of long fiber, according to the results observed in the control group; however, the treatments with Booster ${ }^{\circledR}$ and Biozyme ${ }^{\circledast}$ changed the fiber classification from long to short. Siebert \& Stewart (2006) reported that these characteristics are partially or totally affected by cultivation practices and the type and number of applications of plant regulators.

Table 4. Micronutrient (copper - $\mathrm{Cu}$, iron - Fe, manganese - Mn and zinc - Zn) contents, in the leaves of cotton plants originated from seeds treated with bioregulators on the $60^{\text {th }}$ day after the emergence

\begin{tabular}{lcccc}
\hline \multirow{2}{*}{ Treatment } & $\mathbf{C u}$ & $\mathbf{F e}$ & $\mathbf{M n}$ & $\mathbf{Z n}$ \\
\cline { 2 - 5 } Control group $^{4}$ & $2.90 \mathrm{a}$ & $108.38 \mathrm{~b}$ & $23.52 \mathrm{a}$ & $28.15 \mathrm{a}$ \\
Booster $^{\circledR}$ & $3.42 \mathrm{a}$ & $129.49 \mathrm{a}$ & $29.69 \mathrm{a}$ & $30.08 \mathrm{a}$ \\
Stimulate $^{\circledR}$ & $2.96 \mathrm{a}$ & $121.55 \mathrm{a}$ & $29.95 \mathrm{a}$ & $29.69 \mathrm{a}$ \\
Improver $^{\circledR}$ & $3.36 \mathrm{a}$ & $129.71 \mathrm{a}$ & $30.41 \mathrm{a}$ & $30.02 \mathrm{a}$ \\
Biozyme $^{\circledR}$ & $3.93 \mathrm{a}$ & $128.41 \mathrm{a}$ & $27.71 \mathrm{a}$ & $29.19 \mathrm{a}$ \\
\hline
\end{tabular}

Means followed by the same letter in the column do not differ by Tukey's test at 0.05 probability level

Table 5. Yield (Y) and technological characteristics of micronaire (MIC), fiber length (UHML), fiber uniformity index (UI) and strength (STR) in cotton submitted to application of bioregulators in the seed treatment

\begin{tabular}{|c|c|c|c|c|c|}
\hline Treatm & $\begin{array}{c}\mathrm{Y} \\
\left(\mathrm{kg} \mathrm{ha}^{-1}\right)\end{array}$ & $\begin{array}{c}\text { MIC } \\
\left(\mu \mathrm{g} \mathrm{pol}^{-1}\right)\end{array}$ & $\begin{array}{l}\text { UHML } \\
(\mathrm{mm})\end{array}$ & $\begin{array}{l}\text { UI } \\
(\%)\end{array}$ & $\begin{array}{c}\text { STR } \\
(\text { gf tex } \\
\text { te })\end{array}$ \\
\hline Control gr & $4,236.30 \mathrm{a}$ & $4.35 \mathrm{ab}$ & $31.25 a b$ & $84.47 \mathrm{a}$ & $29.35 b$ \\
\hline Booster $^{\circledR}$ & $4,339.05 \mathrm{a}$ & $4.47 \mathrm{a}$ & 30.12 c & $81.97 \mathrm{C}$ & $32.45 \mathrm{a}$ \\
\hline Stimulate ${ }^{\circledR}$ & $4,217.10 \mathrm{a}$ & $4.12 \mathrm{~b}$ & $30.97 a b$ & $82.92 \mathrm{~b}$ & $31.50 \mathrm{a}$ \\
\hline Improver $^{\circledR}$ & $4,444.50 \mathrm{a}$ & $4.57 \mathrm{a}$ & $31.47 \mathrm{a}$ & $84.47 \mathrm{a}$ & $32.42 \mathrm{a}$ \\
\hline Biozyme $^{\circledR}$ & $4,292.40 \mathrm{a}$ & $4.37 \mathrm{a}$ & $30.45 \mathrm{bc}$ & $83.32 \mathrm{~b}$ & $28.83 \mathrm{~b}$ \\
\hline
\end{tabular}

Means followed by the same letter in the column do not differ by Tukey's test at 0.05 probability level
The uniformity index of fiber length is higher in the control group and in the treatment with application of Improver ${ }^{\circledR}$ in comparison to the remaining treatments. Regarding the treatments with Stimulate ${ }^{\varpi}$ and Biozyme ${ }^{\bowtie}$, the means of uniformity are superior to those observed in the treatment with Booster $^{\circledast}$ (Table 5). According to the classification proposed by Fonseca \& Santana (2002), the uniformity indexes observed in the control and in the seed treatment with Improver $^{\circledR}$ and Biozyme ${ }^{\varpi}$ are considered as high, while those obtained with applications of Stimulate ${ }^{\bowtie}$ and Booster ${ }^{\circledast}$ were classified as regular.

The strength was lower in the control group and in the treatment with Biozyme ${ }^{\varpi}$ in relation to the remaining treatments (Table 5). The strength in the control and in the treatments of seeds with Biozyme ${ }^{\circledast}$ are classified as regular, and in the treatments that received application of Stimulate ${ }^{\varpi}$, Booster $^{\circledast}$ and Improver ${ }^{\oplus}$, the strength is classified as high, according to Fonseca \& Santana (2002).

The observed results do not corroborate with those reported by Gencsoylu (2009) and Çopur et al. (2010). These authors noted that the length, micronaire, strength and uniformity index of cotton fiber were not affected by the application of biostimulants. However, although the biostimulant interferes with technological characteristics of the fiber, the differences do not justify the application of the products, since for most of the studied variables the Biostimulants did not show superiority to the control treatment.

\section{Conclusions}

1. The application of biostimulants via seeds increased the leaf contents of $\mathrm{N}, \mathrm{K}, \mathrm{S}$ and Fe in cotton plants.

2. Biostimulants did not improve cotton yield.

3. The application of the biostimulants Booster ${ }^{\varpi}$, Stimulate and Improve ${ }^{\varpi}$ increases cotton fiber strength.

4. The application of biostimulants in seed treatment does not increase the yield and quality of cotton fiber.

\section{Literature Cited}

Almeida, A. Q.; Soratto, R. P. Teor e acúmulo de nutrientes no feijoeiro em função da aplicação de bioestimulantes. Semina: Ciências Agrárias, v.35, p.2259-2272, 2014. http://dx.doi.org/10.5433/16790359.2014v35n4Suplp2259

Barragán, V.; Leidi, E. O.; Andrés, Z.; Rubio, L.; De Luca, A.; Fernández, J. A.; Cubero, B.; Pardo, J. M. Ion Exchangers NHX1 and NHX2 mediate active potassium uptake into vacuoles to regulate cell turgor and stomatal function in Arabidopsis. Plant Cell, v.24, p.1127-1142, 2012. http://dx.doi.org/10.1105/tpc.111.095273

Binsfeld, J. D.; Barbieri, A. P. C.; Huth, C.; Cabrera, I. C.; Henning, L. M. M. Uso de bioativador, bioestimulante e complexo de nutrientes em sementes de soja. Pesquisa Agropecuária Tropical, v.44, p.8894, 2014. http://dx.doi.org/10.1590/S1983-40632014000100010

Bittner, F.; Oreb, M.; Mendel, R. R. ABA3 Is a Molybdenum cofactor sulfurase required for activation of aldehyde oxidase and xanthine dehydrogenase in Arabidopsis thaliana. The Journal of Biological Chemistry, v.276, p.40381-40384, 2001. http://dx.doi.org/10.1074/ jbc.C100472200 
Brasil. Instrução Normativa n 63 , de 5 de dezembro de 2002. Diário Oficial da União, Brasília, 6 de dezembro de 2002. 2p.

Çopur, O.; Demirel, U.; Karakuş, M. Effects of several plant growth regulators on the yield and fiber quality of cotton (Gossypium hirsutum L.). Notulae Botanicae Horti Agrobotanici Cluj-Napoca, v.38, p.104-110, 2010.

Dourado Neto, D.; Dario, G. J. A.; Barbieri, A. P. P.; Martin, T. N. Ação de bioestimulante no desempenho agronômico de milho e feijão. Bioscience Journal, v.30, p.371-379, 2014.

Dourado Neto, D.; Dario, G. J. A.; Barbieri, A. P. P.; Martin, T. N.; Moschinki, A. Fitorreguladores no crescimento do algodão. Synergismus Scyentifica UTFPR, v.2, p.1-4, 2007.

Ferreira, D. F. Sisvar: A computer statistical analysis system. Ciência e Agrotecnologia, v.35, p.1039-1042, 2011.

Fonseca, R. G.; Santana, J. C. F. Resultados de Ensaio HVI e Suas Interpretações (ASTM D-4605). Campinha Grande: Embrapa Algodão, 2002. 13p.

Gelain, E.; Rosa Junior, E. J.; Mercante, F. M.; Fortes, D. G.; Souza, F. R.; Rosa, Y. B. C. J. Fixação biológica de nitrogênio e teores foliares de nutrientes na soja em função de doses de molibdênio e gesso agrícola. Ciência e Agrotecnologia, v.35, p.259-269, 2011. http:// dx.doi.org/10.1590/S1413-70542011000200005

Gencsoylu, I. Effect of plant growth regulators on agronomic characteristics, lint quality, pests, and predators in Cotton. Journal of Plant Growth Regulator, v.28, p.147-153, 2009. http://dx.doi. org/10.1007/s00344-009-9083-x

Lana, A. M. Q.; Lana, R. M. Q.; Gozuen, C. F.; Bonotto, I.; Trevisan, L. R. Aplicação de reguladores de crescimento na cultura do feijoeiro. Bioscience Journal, v.25, p.13-20, 2009.

Lima, M. M.; Azevedo, C. A. V. de; Beltrão, N. E. de M.; Dantas Neto, J.; Gonçalves, C. B.; Santos, C. G. F. Nitrogênio e promotor de crescimento: efeitos no crescimento e desenvolvimento do algodão colorido verde. Revista Brasileira de Engenharia Agrícola e Ambiental, v.10, p.624-628, 2006. http://dx.doi.org/10.1590/S1415-43662006000300013
Oosterhuis, D. M.; Robertson, W. C. The use of plant growth regulators and other additives in cotton production. Proceedings of the 2000 Cotton Research Meeting, 2000. Fayetteville: University of Arkansas, 2000. p.1-4.

Pedroso Neto, J. C.; Lanza, M. A.; Silva, P. J. Efeitos de micronutrientes, aplicados via sulco e foliar, na cultura do algodoeiro herbáceo. FAZU em Revista, v.3, p.20-24, 2006.

Santos, E. G.; Inoue, M. H.; Mendes, K. F.; Ben, R.; Cavalcante, N. R.; Oliveira, J. S. Eficiência do saflufenacil aplicado como desfolhante em pré-colheita no algodoeiro. Revista Ciências Agrárias, v.57, p.124-129, 2014. http://dx.doi.org/10.4322/ rca.2014.005

Santos, H. G.; Almeida, J. A.; Oliveira, J. B.; Lumbreras, J. F.; Anjos, L. H.; Coelho, M. Z.; Jacomine, P. K. T.; Cunha, T. J. F.; Oliveira, V. À. Sistema brasileiro de classificação de solos, 3.ed., Planaltina: EMBRAPA, 2013. 353p.

Siebert, J. D.; Stewart, A. M. Influence of plant density on cotton response to mepiquat chloride application. Agronomy Journal, v.98, p.1634-1639, 2006. http://dx.doi.org/10.2134/ agronj2006.0083

Silva, J. I. C.; Pereira, F. R.; Cruz, S. C.; Pereira, M. R. R.; Freitag, E. E.; Araújo, H. B.; Villas Boas, R. L. Uso de estimulantes de crescimento radicular associado a doses de fósforo na cultura do feijoeiro. Agrarian, v.2, p.47-61, 2009.

Silva, N. M. Nutrição mineral e adubação do algodoeiro no Brasil. In: Cia, E.; Freire, E. C.; Santos, W. J. Cultura do algodoeiro. Piracicaba: POTAFOS, 1999. p.57-92.

Wang, J.; Wang, H.; Zhao, P.; Han, L.; Jiao, G.; Zheng, Y.; Huang, S.; Xia, G. Overexpression of a Profilin (GhPFN2) promotes the progression of developmental phases in cotton fibers. Plant Cell Physiology, v.51, p.1276-1290, 2010. http://dx.doi.org/10.1093/ pcp/pcq086 